\title{
The Constant Threat of Emerging Viral Diseases
}

\author{
Noor Fatima ${ }^{1}$ and Syed Zaki Muhammad ${ }^{2 *}$ \\ ${ }^{1}$ Liaquat National Hospital and Medical College, Karachi, Pakistan \\ ${ }^{2}$ Dow Medical College, Dow University of Health Sciences, Karachi, Pakistan
}

\begin{abstract}
Respected Editor,
Sudden outbreaks of transpiring viral infections are putting human race into great danger. Different outbreaks in the past such as those of Influenza, Ebola, and Zika viruses and the most recent novel coronavirus, severe acute respiratory syndrome coronavirus 2 (SARS-CoV-2), continue to remind us of our constant vulnerability and warrant constant preparedness [1].
\end{abstract}

Emerging infections could be defined as the ones whose occurrence has increased in the last few years and threatens to increase in the for-coming years. Outbreaks of disease can be initiated by the transmission of a novel pathogen, or due to reemergence of a known pathogen [2].

Viral outbreaks are unpredictable because they result from multifaceted interaction between the virus, vector, host and environment [3]. Outbreaks are likely to cause fast transmission of disease which might cause high morbidity in those affected. Southeast Asia is at a greater risk for the outbreak of pathogenic viruses [2].

Evolutionary changes in pathogens especially viral genetic change that allows cross-species transmission is the basis of zoonosis which puts humans at risk of infecting viruses of animal origin, such was the case in previous outbreaks [4]. This is aided by social and environmental factors - such as increasing global population, rapid urbanization, climate change and, increased susceptibility to infections due to an aging population worldwide - that favor incidence of new viral infections [2].

Quick and precise recognition of emergent pathogens is necessary for rapid countermeasures, better clinical management, and to reduce the extent of these viral infections. For detection, development of diagnostic tests that are cost effective, quick and error free, is essential [2]. One of the widely used molecular method is a polymerase chain reaction (PCR) for identification of viruses; it is rapid, cost-effective, and simple [4].

The capability of viruses to cross species barriers, acclimatize to different environments, and to resist existing vaccines and anti-viral drugs is linked to the accretion of mutations in their genome. Hence, genomic characterization of new viruses is necessary using DNA sequencing strategies that provides critical information

\footnotetext{
*Corresponding Author: Syed Zaki Muhammad, Dow Medical College, Dow University of Health Sciences, Karachi, Pakistan; Email: syedzakimd@gmail.com

Received: March 31, 2020; Revised: April 13, 2020; Accepted: April 14, 2020

DOI: https://doi.org/10.37184/lnjpc.2707-3521.1.18
}

which helps to develop diagnostic tests, improved drugs, and effective vaccine design [2, 4].

Vaccination has proved to be the most effective technique to eliminate pathogenic viruses. Vaccines provide protection by inducing protective immunity and their development requires identification of the specific antigen that elicits an immune response [2].

The current outbreak of SARS-CoV-2 has seen rapid response from the scientific community with isolation and genetic sequencing of the virus completed within a short time. The genetic sequence facilitates the production of diagnostic PCR tests for the detection of SARS-CoV-2 [5]. Various attempts at developing a vaccine against SARS-CoV-2 are underway, with many of the candidates at preclinical stages and few of them in clinical stages [6].

To reduce the impact of emerging viral diseases in future, establishing local laboratory capacity is critical which helps in surveillance, diagnosis, and monitoring of emerging diseases. This could be achieved using improved laboratory facilities and equipment, and building human resource.

\section{CONFLICT OF INTEREST}

Authors declare no conflicts of interest.

\section{ACKNOWLEDGEMENTS}

All authors contributed equally to manuscript design and preparation. Authors have revised the manuscript critically and approved the final version.

\section{REFERENCES}

1. Luo G, Gao SJ. Global health concern stirred by emerging viral infections. J Med Virol 2020; 92: 399-400.

2. Artika IM, Wiyatno A, Ma'roef CN. Pathogenic viruses: molecular detection and characterization. Infect Genet Evol 2020; 81: 104215.

3. De Jong W, Rusli M, Bhoelan S, Rohde S, Rantam FA, Noeryoto $\mathrm{PA}$ et al. Endemic and emerging acute virus infections in Indonesia: an overview of the past decade and implications for the future. Crit Rev Microbiol 2018; 44: 487-503.

4. Munoz LS, Garcia MA, Gordon-Lipkin E, Parra B, Pardo CA. Emerging viral infections and their impact on the global burden of neurological disease. Semin Neurol 2018; 38: 163-75

5. Hui DS, Azhar El, Madani TA, Ntoumi F, Kock R, Dar O, et al. The continuing 2019-nCoV epidemic threat of novel coronaviruses to global health-the latest 2019 novel coronavirus outbreak in Wuhan, China. Int J Infect Dis 2020; 91: 264-6.

6. Thanh Le T, Andreadakis Z, Kumar A, Román RG, Tollefsen S, Saville M, et al. The COVID-19 vaccine development landscape. Nat Rev Drug Discov 2020; [Online ahead of print]. 